\title{
The Impact of Monetary and Fiscal Policy on Stock Market Performance: Evidence from Multiple Countries
}

\author{
Xiqing Chen \\ Sydney Girls High School, Sydney, New South Wales, 2010, Australia \\ Corresponding author.Email: gaoming@cas-harbour.org
}

\begin{abstract}
Through the comprehension of secondary data and analysis from different sources, this paper explores the impacts of monetary and fiscal policy on the stock market with evidence from Australia, China, 11 member countries of the Eurozone (combined) and the United States. In the theoretical aspect, monetary policy can impact stock market performance through the interest rate channel, credit channel and investors' expectations. However, results indicate that the effect of monetary policy on stock market performance varies between countries due to different market expectations. It can be concluded that the anticipation of regular announcement periods often corresponds to a less volatile stock market index than surprise announcements. On the fiscal side, its relationship with stock market performance can be explained through either the Keynesian, Ricardian or classical economic theory. The conclusions drawn reflect the stock market responding in a negative manner following an expansionary stance under normal macroeconomic conditions, whilst a positive correlation is seen during periods of economic downturn. Furthermore, an indirect relationship between fiscal policy and stock market performance is interpreted through the channel of money supply. Thus, the effects of macroeconomic policies on stock market performance shown in this paper could help investors and governments in their decision making, leading to more effective allocation of resources.
\end{abstract}

Keywords: Monetary policy, Interest rates, stock market, fiscal policy

\section{INTRODUCTION}

Over the last decades, there has been a prominent use of both monetary and fiscal policies in light of major economic events, aimed to counterbalance the business cycle and achieve the government's economic objectives. It is crucial to note that the adjustments of these policies can create an impact on the stock market, as the movements of stock prices are closely interrelated with the health of the economy. However, a significant number of past studies had the area focused on the correlation between monetary policy and the stock market, yet only a few concentrated on the impact of macroeconomic policy mix. Fiscal policy should be examined together with monetary policy as both serve an important role in influencing stock market performance. Thus, this paper aims to assess the impact of monetary and fiscal policies on the stock market with relevant evidence from Australia, China, 11 member countries of the Eurozone (combined) and the United States using secondary studies.

\section{THE RELATIONSHIP BETWEEN MONETARY POLICY AND STOCK PRICES}

\subsection{Theoretical framework}

The prices of stocks are determined by the following factors: 1 . The expected profits from firms 2 . The riskfree rate of return on US Treasury bonds 3. The risk premium that investors would earn in addition to the interest rates received from the holding of government bonds rather than stock purchases. Further, stocks are claims on future economic output [1], thus under the assumption that monetary policy has real economic effects of encouraging investment, stock markets should be influenced by monetary conditions. This can be interpreted through the present value model in Equation (1), where the stock price (St) is the present value of expected future dividends $(\mathrm{Dt}+\mathrm{j})$ : 


$$
S_{t}=E_{t}\left[\sum_{j=1}^{K}\left(\frac{1}{1+R}\right)^{j} D_{t+j}\right]
$$

Et: the conditional expectations operator based on information of market participants at time $t$

$\mathrm{R}$ : rate of return used to discount future dividends

$\mathrm{K}$ : the time one expects to hold the stock

The assumptions of this model are that the discount factors used by market participants correspond to market interest rates and that monetary policy changes exert an indirect effect on the firms' stock value by altering expected future cash flows [3].

Therefore, the impact of monetary policy on stock prices can be explained through the interest rate channel. For an expansionary monetary policy stance, central banks conduct open market operations (OMOs) to purchase secondary government bonds from commercial banks, injecting a greater supply of money. Supported by the transmission mechanism that states monetary policy decisions are transmitted into changes in the economy, this action by the central bank lowers the cost of loanable funds for investors from downward pressures of market interest rates (assuming that a lowered cash rate in the money market has a flow on effect on market interest rates). This encourages investors to conduct greater levels of borrowing and subsequent portfolio investment such as stock purchases, driving up prices of stocks.
The relationship between monetary policy and the stock market can also be interpreted through the credit channel. From a firm's perspective [4], higher levels of corporate investment activity from cheaper rates of borrowing are expected to generate a higher future cash flow. Under the assumption that the firm's market value is affected by the present value of its future cash flows, this should increase the firm's market value in the long run. Furthermore, the influence on investor's expectations from monetary policy can also impact stock prices. Monetary policy often consists of a time lag between 6 to 18 months for it to have an obvious impact on the economy. This is because time is required for consumers and firms to be responsive to changes in interest rates and adjust their borrowing behaviours. Therefore, it can be argued that stock prices are attributed to investors' expectations about future dividends and expected returns regarding forecasts of the effects of monetary policy on the economy.

\subsection{The actual situation}

\subsubsection{Findings from Australia}

Alexandra Brown's [4] research utilised the Ordinary Least Squares and Robust Standard Errors method to ascertain the reaction of the Australian stock market to cash rate changes. Overall, the response of the Australian stock market on monetary policy decisions by the Reserve Bank of Australia (RBA) is minimal. From the datasets in figure 1, the All Ordinaries index has a similar trend increase to the cash rate prior to the global financial crisis (GFC) in 2008.

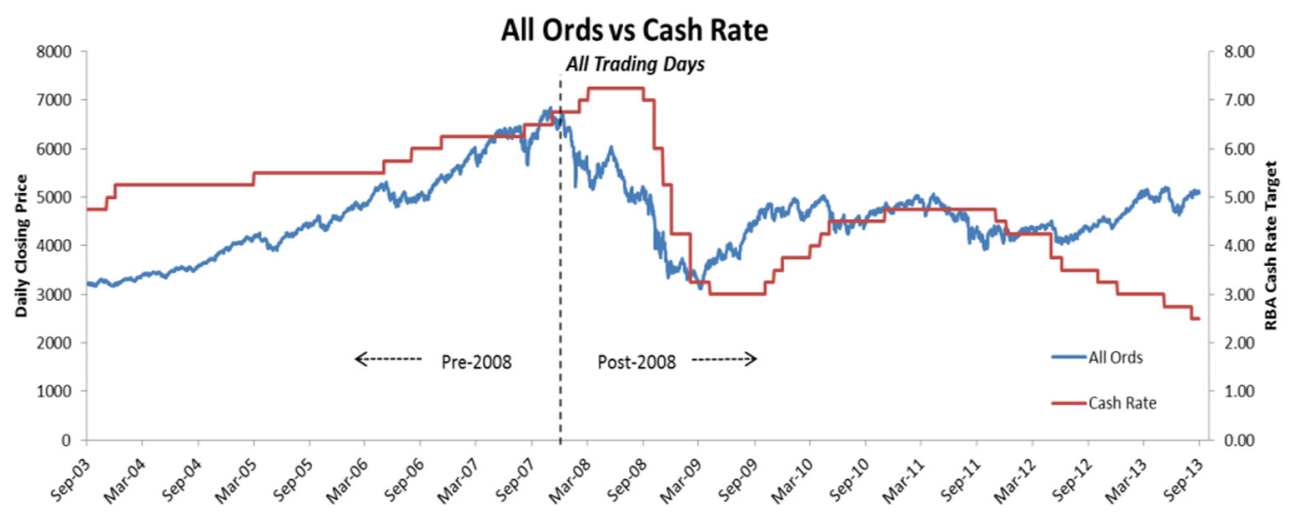

Figure 1. All Ords Price and policy decisions for all trading days [5].

This contradicts the assumption made previously, as in the theoretical aspect, a sustained period of cash rate increase (contractionary monetary policy) should cause a decline in the index as investors are discouraged to conduct stock purchases due to greater expense of funds, contributing to lower activities in the stock market. This could be because All Ords is more responsive to changing economic conditions rather than monetary policy changes, as
Australia's sustained period of economic growth during the mining boom between 2003 to 2007 provided greater confidence for investors to purchase stocks anticipating a profitable return. Further, during the GFC, the All Ords had a much earlier decline than the RBA's announcement of cash rate reductions, supporting the previous claim that changes in economic conditions had a more significant impact upon the stock market than 
monetary policy adjustments. However, the data noted a divergence since 2012, as the RBA's successive expansionary measures to promote economic recovery post GFC implies a greater reliance from the stock market on monetary decisions during this period of time.

There is also no significant impact on stock returns for large changes to the cash rate target greater than 25 basis points on the event date.

Table 1. Observations with cash rate change greater than 25 basis points on event date [6].

\begin{tabular}{cccc} 
Date of Announcement & Cash Rate Target $\%$ & Raw Change b.p. & 1-day Returns \% \\
\hline $10 / 7 / 2008$ & 6.00 & -100 & 1.16 \\
$11 / 4 / 2008$ & 5.25 & -75 & -0.08 \\
$12 / 2 / 2008$ & 4.25 & -100 & -4.11 \\
$2 / 3 / 2009$ & 3.25 & -100 & 0.16 \\
$5 / 1 / 2012$ & 3.75 & -50 & 0.67 \\
\hline
\end{tabular}

Despite recording a significant fall of $4.11 \%$ after RBA's 100 basis points reduction in cash rate $(2 \mathrm{Dec}$ 2008) in response to declining economic conditions during the GFC, the table indicates the market moved between $-0.08 \%$ and $1.16 \%$. This implies that the market is more responsive to changes in macroeconomic indicators such as employment levels and inflation rates than monetary policy decisions.

\subsubsection{Findings from China}

Xin Jin, Mengting Li, and Tianxi Jin [7] established a VAR model to analyse the effect of monetary policy on the Chinese stock market and found that the Shanghai Stock Exchange Composite Index (SSE) is more responsive to changes in monetary policy decisions announced by the People's Bank of China (PBOC). During the GFC, despite an initial announcement of Reserve Requirement Ratio (RRR) cut, the stock market continued to fall through mid-2008 and reached its lowest point in October 2008. This corresponds to the previous explanation regarding the greater responsiveness of the stock market to declining economic conditions than a single announcement of monetary policy, reflecting the insignificance of the transmission mechanism in this context.

However, the paper from Yong Tong et. al [8] found that the subsequent rise of SSE post October 2008 reflects the strong influence of successive cuts in RRR, totaling to four between October and December of 2008 responding to severe economic declines during the GFC. It also notes that the Shanghai stock market reflects a greater volatility during an expansionary monetary policy stance than a contractionary stance, thus monetary policy changes in an economic downturn invites a larger response from the stock market.

The discrepancy in findings between Australia and China could be attributed to the different expectations from market participants. The People's Bank of China does not provide signals prior to its announcement of a cash rate change; thus, the market often cannot predict the exact date of announcement. This means market activities may reflect a greater degree of participant anticipations for an upcoming monetary policy change. In contrast, the Reserve Bank of Australia's regular announcement of cash rate targets on a monthly basis meant that market participants can factor the expected future changes prior to this day, thus there is no significant change to the stock index even with changes above 25 basis points.

\section{THE RELATIONSHIP BETWEEN FISCAL POLICY AND STOCK PRICES}

\subsection{Theoretical framework}

The discussion of the relationship between fiscal policy and the stock market varies according to different economic theories.

In the Keynesian theory, fiscal policy relates to the use of the government expenditure and revenue to influence the level of aggregate demand in order to achieve macroeconomic objectives such as to counterbalance a downturn in the business cycle. A rise in government expenditure could lead to an increase in the level of disposable income, for example, unemployment benefits, meaning individuals have greater opportunity to invest in the capital market, pushing up demand for stocks. This raises the prices of stocks in the market, suggesting an indirect relationship between government expenditure and stock prices. Also, increased fiscal measures stimulate higher levels of consumer confidence and consumption, meaning firms experience a corresponding increase in sales and earnings. This translates to a rise in stock prices.

However, in the Ricardian view, fiscal tools do not have an impact on the aggregate demand as it assumes that borrowings from the private sector will be offset by private savings of rational households. 
Hence, there will also be no effect on stock market prices. The theory assumes that individuals will base off their expectation of future tax increases to decide their level of investment and consumption at the present moment due to precautionary motives. Therefore, it argues that the government's attempt to boost economic growth through debt-financed government spending (as in most cases around the world) will not be effective as individuals expect a higher tax collection in the future as a means to repay the debt. This behaviour offsets the increase in the government spending component of the aggregate demand due to reduction in consumption and investment, thereby translating to a lower level of stock purchases, placing downward pressure on stock prices.

Further, classical economic theory also supports the discussion for a possible contractionary effect of fiscal spending by proposing the crowding out effect. This occurs when the government finances its budget deficit by borrowing from the private sector, increasing competition for the domestic pool of funds. This places upper pressure on real interest rates, meaning loanable funds become more expensive. This can discourage the investment component of the aggregate demand, causing a decline in stock prices.

\subsection{The actual situation}

\subsubsection{Findings from the Eurozone}

Pasquale Foresti and Oreste Napolitano's [9] examination for a panel of 11 member countries of the Eurozone over the period from 1999 to 2012 using panel DOLS estimations suggested that fiscal measures had a varied impact on stock markets under different macroeconomic conditions. Statistics found that the elasticity of the stock markets indexes to changes in public expenditure and revenues are 1.447 and 1.349 respectively, hence the assumption that market participants adhere to a pure Ricardian perspective can be eliminated, as a relationship is apparent. Beginning from the third quarter of 2007, the reaction of stock market indexes to an increase in fiscal spending becomes positive, whereas a decline in stock prices is seen with a raise in taxation.

Overall, the results provided from the paper suggests that there is a negative response from the stock market following an expansionary fiscal policy under normal macroeconomic conditions. The decline in stock market index can be attributed to market participant's greater acceptance of fiscal consolidation during this time in the hope that a reduction in fiscal stimulus can place downward pressure on the demand for domestic funds, meaning the market reacts in anticipation of a potential crowding out effect if excessive financing of the budget deficit through the domestic sector occurs. This relationship also holds during periods of sovereign debt troubles, since stock markets relied on the assurance of a sustainable public debt as seen during the European Sovereign Debt crisis from 2010-12.

However, when the market could not be selfsufficient during periods of economic contraction (i.e. the global financial crisis from 2008-09), an adoption of a pure Keynesian manner can be seen as successive periods of expansionary fiscal measures invited a positive response from the stock market. This is because under financial stress, the stock market often requires the support from the government as the sentiment to invest is unprecedentedly low since individuals are incentivised to withdraw funds from the stock market due to precautionary motives. Similarly, consumer confidence is dampened, resulting in lower revenue for corporations. Therefore, strong fiscal support during recessions is likely to boost the confidence of market participants, inducing an increase in stock prices.

\subsubsection{Findings from the United States}

In contrast, findings from Ioannis Chatziantoniou, David Duffy and George Filis [10] for the United States' Dow Jones Index over the period from 1991 to 2010 do not suggest that fiscal policy exerts a direct impact on the stock market. However, an indirect relationship found through the comprehension of data in a structural VAR model suggests that US government spending exhibits a positive and significant effect on money supply, in turn, producing a positive influence on interest rates and stock market performance. This is because an increase in money supply results in a corresponding decline in real market interest rates, meaning stocks become a more attractive form of investment since the lower returns on savings in a bank or Treasury bills discourages investors from participating in such activities. Therefore, the finding of a correlation between money supply and fiscal policies provides evidence of an existing indirect relationship between fiscal policy and the US stock market development.

\section{CONCLUSION}

By analysing the impacts of monetary and fiscal policy on the stock market using secondary data and studies, it can be concluded that the individual stances of the respective policies do have an impact on the stock market. Stock prices can be affected by macroeconomic policies via direct channels, such as a deliberate adjustment of interest rates to influence corporate returns and the decisions for portfolio 
investment, as well as indirect channels, such as money supply and the Ricardian view of the crowding out effect. However, the extent to which monetary and fiscal policy influence the stock market index is still largely dependent on market participant expectations on the general macroeconomic condition, which varies across different countries. Furthermore, it should be noted that these interpretations only offer a minimal explanation for the overall variability of stock market performances. Meanwhile, there is also a need to consider the economic conditions of different countries as different stock markets may be responsive to different factors. Nevertheless, the evidence provided still offers a valuable framework for policy makers in their designing of monetary and fiscal policies when considering its impact on the health of the stock market.

\section{REFERENCES}

[1] Patelis, A. Stock Return Predictability and the Role of Monetary Policy. Journal of Finance, 1997(52): 1951-1972. [Accessed 18 Jul. 2021]

[2] Ioannidis, C. and Kontonikas, A. Present value or discounted cash flow model. 2006.

[3 Ioannidis, C. and Kontonikas, A. Monetary Policy and the Stock Market: Some International evidence. 2006. [online] . Available at:https://www.gla.ac.uk/media/Media_219105_ smxx.pdf [Accessed 22 Jul. 2021].

[4] Brown, A. The Reaction of the Australian Stock Market to Monetary Policy Announcements from the Reserve Bank of Australia. Economic Record. 2016, 93(300): 20-41. Available at: https://www.apra.gov.au/sites/default/files/Brow n-The-reaction-of-the-Australian-stock-marketto-monetary-policy-announcements-from-theRBA.pdf [Accessed 11 Aug. 2021].

[5] Brown, A. All Ords vs Cash Rate. 2014.

[6] Brown, A. Observations with cash rate change greater than 25 basis points. 2014.

[7] Jin, X., Li, M. and Jin, T. Research on the Conducting Effect of Monetary Policy on Stock Market Based on Investor Sentiment. International Journal of Trade, Economics and Finance, 2020, 12(3): 62-68. [Accessed 27 Aug. 2021]

[8] Tang, Y., Luo, Y., Xiong, J., Zhao, F. and Zhang, Y.-C. Impact of monetary policy changes on the Chinese monetary and stock markets. Physica A: Statistical Mechanics and its Applications, 2013, 392(19): 4435-4449. [Accessed 31 Aug. 2021].
[9] Foresti, P. and Napolitano, O. On the Stock Market Reactions to Taxation and Public Expenditure. SSRN Electronic Journal, 2016, 115 Available

at: http://aei.pitt.edu/93633/1/LEQSPaper115.pdf [Accessed 10 Sep. 2021].

[10] Chatziantoniou, I., Duffy, D. and Filis, G. (n.d.). Stock Market Response to Monetary and Fiscal Policy Shocks: Multi- Country Evidence. [online] Available at: http://eprints.bournemouth.ac.uk/20575/1/Econo mic\%20Modelling_GF.pdf [Accessed 09 Aug. 2021]. 